\title{
SOLUSI BISNIS ONLINE DIMASA PANDEMIC PADA RUMAH TAHSIN AL HIKAM, PONDOK KACANG TIMUR TANGERANG SELATAN
}

\author{
Mada Faisal $^{1}$, Aris Ariyanto ${ }^{2}$, Agus Sudarsono ${ }^{3}$ Ivantan $^{4}$, Purwanti $^{5}$ \\ Universitas Pamulang \\ Email: dosen02471@unpam.ac.id
}

\begin{abstract}
Currently learning digital marketing or learning online marketing is one of the things that everyone does if they don't want to be eroded by the times. Learning online marketing can be done by anyone. Including the students. The reason is, currently many pesantren graduates have also followed the flow of technological developments by studying digital marketing. It doesn't feel right, if you think that pesantren graduates only study the religious sciences and the Koran. Because in addition, santri graduates must also be able to follow the flow of technological developments by utilizing technological sophistication. This activity aims to motivate and provide counseling in managing and thinking about effective governance on solutions to develop the potential of students and santri teachers to learn online business as an effort to achieve the goal of building an economy for Al-Hikam's tahsin and tahfiz houses. The program we propose is "Online Business Solutions during the Pandemic Period at Al Hikam's Tahsin House, Pondok Kacang Timur, South Tangerang. The form of this program is the development of the community in utilizing social technology and internet marketing which has a positive impact on students and teachers of the Tahfids house and Al-Hikam tahsin to be able to open entrepreneurs. The methods that will be used in achieving the goals are various methods such as lectures, discussions and questions and answers, as well as regular community assistance. This program has long-term results and goals based on several forms of service, namely realizing a business and the ability to trade online for supplies in the future.
\end{abstract}

Keywords: Online Business , Covid 19, Pandemic

\begin{abstract}
Abstrak
Saat ini belajar digital marketing atau belajar pemasaran online merupakan salah satu hal yang dilakukan oleh setiap orang jika tidak ingin tergerus oleh perkembangan zaman. Belajar pemasaran online bisa dilakukan oleh siapa saja. Termasuk para santri. Pasalnya, saat ini sudah banyak lulusan pesantren yang juga mengikuti arus perkembangan teknologi dengan mempelajari digital marketing. Rasanya kurang tepat, jika anda berpikir bahwa lulusan pesantren hanya mempelajari ilmu-ilmu agama dan mengaji saja. Karena di samping itu, lulusan santri juga harus bisa mengikuti arus perkembangan teknologi dengan memanfaatkan kecanggihan teknologi. Kegiatan ini bertujuan untuk memotivasi dan memberikan penyuluhan dalam mengelola dan memikirkan tata kelola yang efektif tntang solusi
\end{abstract}


mengembangkan potensi para santri maupun para guru santri untuk belajar bisnis online sebagai upaya pencapaian tujuan untuk membangun perekonomian untuk rumah tahsin dan tahfiz Al - Hikam. Program yang kami usulkan adalah"Solusi Bisnis Online Dimasa Pandemic Pada Rumah Tahsin Al Hikam, Pondok Kacang Timur, Tangerang Selatan. Bentuk dari program ini adalah pengembangan masyarakat dalam memanfaatkan teknologi dan internet marketing sosial yang dampak positifnya bagi para santri maupun tenaga pengajar para rumah tahfids dan tahsin Al-Hikam untuk mampu membuka wirausaha. Metode yang akan dipakai dalam pencapaian tujuan yaitu dengan berbagai metode seperti ceramah, diskusi dan tanya jawab, serta pendampingan bagi masyarakat secara rutin. Program ini mempunyai mempunyaihasil dan tujuan jangka panjang berdasarkan beberapa bentuk pengabdian yakni mewujudkan sebuah usaha dan kemampuan untuk berdagang secara online untuk perbekalan di masa yang akan datang.

\section{Kata Kunci: Bisnis Online, Pandemic, Covid 19}

\section{A. PENDAHULUAN}

Memasuki bulan kedelapan di tahun 2020, iklim bisnis tanah air sedang lesu, pasalnya pandemi COVID-19 yang sedang merebak membuat aktivitas usaha mengendur. Sejumlah sektor usaha yang terkena dampak ini adalah industri manufaktur, industri retail, wisata, perhotelan, penerbangan, dan lainnya. Bahkan, Sri Mulyani mengatakan bahwa dampak ekonomi yang berasal dari pandemi virus covid-19 lebih kompleks dibandingkan krisis yang pernah menimpa Indonesia pada tahun 1997-1998 dan 2008-2009 seperti dilansir dari detik.com. Pandemi Corona Virus Disease 19 (Covid-19) yang melanda saat ini memiliki dampak besar bagi seluruh dunia. Dikarenakan seriusnya permasalahan Covid-19, pemerintah terpaksa mengeluarkan kebijakan Pembatasan Sosial Skala Besar (PSBB), serta adanya kebijakan untuk di rumah saja, sesuai dengan protokol kesehatan yang ada, sebagai upaya memutus mata rantai penyebaran Virus Corona.

Kebijakan-kebijakan yang dikeluarkan pemerintah tersebut mengakibatkan banyaknya perubahan-perubahan terjadi yang sebelumnya justru tidak pernah terpikirkan oleh banyak orang. Salah satunya perubahan dalam dunia pendidikan. Wabah ini mengakibatkan perubahan total pada proses pembelajaran, dimana kegiatan belajar mengajar yang tadinya berjalan normal diadakan di sekolah, kampus, pesantren, dan lain-lainya, tiba-tiba saja berubah yang mengharuskan siswa untuk belajar dari rumah. Proses pembelajaran dilakukan secara online (pembelajaran Daring), dimana guru dan para siswa melakukan kegiatan belajar mengajar menggunakan aplikasi yang diinstalkan ke HP (telepon seluler) atau laptop. Orang tua juga diminta untuk bekerjasama dengan cara mendampingi siswa dalam proses pembelajaran online tersebut. Akan tetapi, kebijakan belajar dari rumah dengan dampingan orang tuanya tersebut, ternyata tidak semudah apa yang kita bayangkan. Banyak kendalakendala yang dirasakan disana, mulai dari fasilitas pendukung seperti jaringan internet, perangkat yang dimiliki siswa, serta kemampuan masing-masing orang tua siswa juga berbeda.

Permasalahan yang dihadapi adalah belum ada pemberdayaan ibu-ibu rumah tangga dalam meningkatkan pendapatan rumah tangga, kurangnya pengetahuan pemanfaatan limbah kain perca. Tujuannya untuk meningkatkan keterampilan kreasi dan inovasi kerajinan tangan dari kain perca dalam peningkatan ekonomi keluarga. Kain perca juga dapat dijadikan usaha 
yang bergerak dibidang industri rumah tangga, sehingga dapat meningkatkan kesejahteraan hidup. Dalam pemanfaatan kain perca kami memilih pembuatan bros, bros dapat dibuat sebagai pelengkap fashion. Hal ini cukup menjanjikan karena dapat menjadi potensi usaha dengan biaya hemat memanfaatkan limbah kain perca bisa melakukan bisnis sendiri maupun kelompok.

Berbagai kendala tersebut menjadi sebuah tantangan, baik bagi para siswa, orang tua maupun para guru. Mereka harus lebih giat lagi belajar, harus lebih siap dan mampu menguasai teknologi, agar ke depannya tidak tergilas arus zaman. Karena siapa yang akan menyangka, dengan terjadinya wabah Covid-19 ini, tiba-tiba saja tidak diperbolehkan untuk bertatap muka dan berkumpul. Dengan demikian, lembaga-lembaga atau instansi-instansi yang ingin mengadakan rapat, harus dilakukan secara online dengan aplikasi yang sebelumnya tidak banyak orang yang paham.

Pandemi virus Corona telah membawa dampak yang cukup terasa bagi pelaku usaha di seluruh dunia. Termasuk di Indonesia. Kebanyakan pelaku usaha terpaksa menghentikan aktifitas usahanya, karena kebijakan yang dikeluarkan pemerintah. Tak bisa dipungkiri Covid-19 telah mengubah kehidupan banyak orang dan menciptakan berbagai kebiasaan baru. Salah satu dampak yang sangat terasa adalah perubahan ekonomi di berbagai sektor. Dampak perubahan tersebut ada sebagian orang yang mengalami Pemutusan Hubungan Kerja (PHK) atau kehilangan pendapatan. Di sisi lain perkembangan teknologi yang pesat dan jaringan internet membawa berkah tersendiri karena di masa krisis seperti sekarang mampu memberikan dampak positif yakni bermunculan berbagai peluang usaha online yang bisa ditekuni hal inilah yang akan di terapkan di Rumah Tahsin dan Tahfidz Yayasan Al-Hikam yang beralamat Jl. Pondok Kacang Timur Tangerang Selatan.

Saat ini belajar digital marketing atau belajar pemasaran online merupakan salah satu hal yang dilakukan oleh setiap orang jika tidak ingin tergerus oleh perkembangan zaman. Belajar pemasaran online bisa dilakukan oleh siapa saja. Termasuk para santri. Pasalnya, saat ini sudah banyak lulusan pesantren yang juga mengikuti arus perkembangan teknologi dengan mempelajari digital marketing. Rasanya kurang tepat, jika Anda berpikir bahwa lulusan pesantren hanya mempelajari ilmu-ilmu agama dan mengaji saja. Karena di samping itu, lulusan santri juga harus bisa mengikuti arus perkembangan teknologi dengan memanfaatkan kecanggihan teknologi.

Prospek bisnis online di era pandemi Covid-19 yang dinilai terus memiliki peluang yang besar untuk dapat meraup peluang sehingga dapat bangkit di tengah kebiasaan baru Bisnis e-commerce menjadi kebutuhan utama publik dalam bertransaksi di masa pandemi ini, mengingat masyarakat takut berbelanja secara langsung sehingga untuk pembelian beberapa kebutuhan dilakukan secara online melalui platform-platform e-commerce. Sebagaimana kegiatan bisnis pada umumnya, bisnis online juga tidak lepas dari pengawasan hukum. Sebenarnya banyak undang-undang yang terkait dengan bisnis online, seperti: UndangUndang no.7 Tahun 2014 tentang Perdagangan mengatur segala sesuatu tentang perdagangan. Sebagai salah satu bentuk perdagangan yang dilakukan dengan media internet, tentu saja Undang-undang perdagangan mengatur hal tersebut. Pemerintah Republik Indonesia, dalam hal ini Kementerian Perdagangan, membuat Undang-Undang Perdagangan dengan maksud untuk memajukan sektor perdagangan di Indonesia. Dalam pasal 2 (a) UU no.7 tahun 2014 tentang Perdagangan disebutkan bahwa "Kebijakan perdagangan disusun berdasarkan asas kepentingan nasional". Dalam hal ini, kepentingan nasional tentu saja meliputi pertumbuhan ekonomi, peningkatan daya saing perdagangan, melindungi produksi dalam negeri serta penguatan UMKM dan lain sebagainya. 


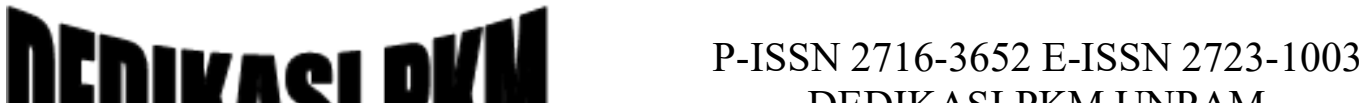 \\ DEDIKASI PKM UNPAM \\ Vol. 2, No. 1, Januari 2021, Hal (44-49) \\ @Prodi Manajemen Fakultas Ekonomi Universitas Pamulang}

\section{B. METODE PELAKSANAAN}

Metode kegiatan ini berupa pelatihan bisnis atau berdagang secara online yang berbentuk diskusi dan ceramah dengan hasil pembuatan akun media sosial.

Berikut ini adalah tahapan pelatihan yang dilakukan:

1. Survei Tempat Pelaksanaan Kegiatan

Kegiatan ini dimaksudkan untuk menggali informasi tentang kondisi geografis dan kondisi masyarakat didaerah tempat kegiatan. Informasi tersebut berupa lokasi, permasalahan yang dihadapi dalam pada lokasi tersebut

2. Persiapan Sarana dan Prasarana.

Kegiatan ini dimaksudkan untuk merencanakan kebutuhan baik sarana dan prasarana yang akan digunakan dalam pelaksanaan kegiatan dengan tetap memperhatikan kebutuhan masyarakat secara umum dan khusus demi tercapainya target pengabdian kepada masyarakat. Sarana dan prasarana yang dimaksud berupa projektor, spanduk daln lain-lain.

3. Pelaksanaan Kegiatan.

Setelah melakukan survey dan persiapan sarana dan prasarana maka pelaksanaan kegiatan dilaksanakan oleh pengusul besrta anggota dan beberapa mahasiswa. Kegiatan yang dilakukan adalah berupa pelatihan atau penyuluhan dalam bentuk pertemuan secara langsung dengan para santri dan santriwati serta tenaga pengajar pada Rumah Tahsin dan Tahfidz Al-Hikam, Pondok Kacang Timur, Tangerang Selatan

4. Monitoring dan Evaluasi

Kegiatan ini dimaksudkan untuk meninjau perkembangan aktualisasi masyarakat terhadap kegiatan yang telah dilakukan sebelumnya dengan harapan dapat dilaksanakan sesuai dengan teori yang telah di peroleh melalui kegiatan yang telah dilaksanakan. Evaluasi juga bertujuan untuk memahami pola pemahaman masyrakat terhadap informasi atau pengetahuan baru yang diperoleh dari pelaksana kegiatan. Hasil ini diharapkan mampu menjadi dasar pengembangan para santri dan santriwati pada Rumah Tahsin dan Tahfidz Al-Hikam, Pondok Kacang Timur, Tangerang Selatan untuk menghetahui tata cara memasarkan produk melalui online.

Dalam pelatihan ini, nara sumber berfokus kepada para santri-santriwati dan tenaga pengajar pada rumah tahsin al hikam, pondok kacang timur, tangerang selatan. .Dimana strategi ini dipilih karena era saat ini adalah era New Media, dimana media sosial adalah cara yang murah dan effectif dalam melakukan penyebaran informasi.

\section{HASIL DAN PEMBAHASAN}

Peserta yang hadir sebanyak 30 orang yang terdiri dari perwakilan ketua Yayasan para santri dan tenaga pengajar, serta para dosen dan mahasiswa Universitas Pamulang. Kegiatan dilaksanakan melalui diskusi tanya jawab, dengan cara para narasumber memberikan penyuluhan dan diikuti oleh para peserta yang kumpul di Aula Rumah Tahsin dan Tahfidz Al-Hikam yang antusias menyimak menggunakan sebuah laptop yang disambungan ke LCD

Kegiatan berjalan baik dan lancer, banyaknya peserta yang antusias untuk bertanya,berdiskusi dan praktek langsung menggunakan media sosial untuk mempromosikan produk melalui online yang menjadikan para nara sumber lebih bersemangat lagi untuk memberikan penyuluhan.

Penggunaan teknologi digital berupa media sosial telah memengaruhi semua aspek termasuk aspek promosi tempak wisata yang memang sedang digalakkan oleh pemerintah setempat, tentu tidak terlepas dukungan warga masyarakat sekitar khususnya para santri dan santriwati rumah tahsin yang memang masih relatif berusia muda. Penggunaan media sosial 
diharapkan dapat digunakan sebagai salah satu pembuka semakin dikenal oleh dunia luas dan bisa membuka peluang usaha usaha baru juga seperti jilbab, Al-Quran, dan peralatan santri atau usaha lain yang nantinya akan membuka usaha berdagang secara online untuk bekal dimasa yang akan datang. Dengan adanya media sosial memungkinkan banyak calon pembeli memperoleh seluruh informasi mengenai produk melalui internet, dan memungkinkan para pembeli untuk selalu memantau dan mengikuti media sosial atau akun-akun jual beli online atau online shop, baik akun Instagram, Youtube, Facebook, Twiteer, Line atau akun-akun yang lain yang dikelola.

Model promosi melalu media sosial sesuai dengan perkembangan teknologi komunikasi dan informasi saat ini. Dengan diadakan pelatihan promosi melalu media sosial peserta penyuluahn nantinya dituntut lebih aktif dalam dalam mengelola akun-akun media sosialnya agar produk yang akan dijual mampu bersaing di pasar online. Diera digital promosi produk memang tidak cukup hanya dilakukan melalui media tradisional atau pun konvensional. Media konvensional adalah media yang berbayar, misalkan iklan luar ruang, seperti baliho, billboard, brosur, leaflet, iklan di media cetak, radio, dan juga televisi. Media-media tersebut dinilai berbiaya tinggi, tidak interaktif, kurang dapat diperbaharui setiap saat, dan sulit diprediksi efektivitasnya. Selain itu, tidak dapat diketahui secara langsung respons, minat beli masyarakat menurun. Perubahan metode promosi akan semakin berkempang pesat, jika media sosial tersebut dikeloa dengan baik, serta menggunakan trik atau cara cara jitu agar promosi tepat sasaran yaitu menyembar dengan cepat dan tepat. Segmen yang tepat tentu tidak akan membuat sia-sia promosi menggunakan media sosial.

\section{KESIMPULAN DAN SARAN}

\section{Kesimpulan}

Hasil kegiatan PkM di rumah tahsin di lokasi berjalan dengan lancar. Meski pada masa PSBB namun dengan tetap melaksankan protocol sesuai anjuran pemerintah setempat Perserta terlihat antusias mengikuti pemyuluhan walau keterbatasan sarana prasana. Pelatihan penggunaan sosial media memberikan kemudahan masyarakat dalam melakukan kegiatan berbisnis online agar lebih dikenal masyarakat luas sehingga dapat menumbuhkan semangat berwirausaha untuk para santri pada Rumah Tahsin dan Tafidz Al-Hikam.

\section{Saran}

Berikut adalah beberapa saran untuk Yayasan Rumah Tahsin dan Tafidz Al-Hikam maupun masyarakat setempat dalam meningkatkan potensi diri para santri

1. Membuat akun media sosial sebagai media terpisah dari akun pribadi.

2. Post foto-foto menarik tentang produk yang akan dijual secara berkala dan rutin,

3. Usahakan setiap posting foto dan kegiatan yang berkaitan dengan rumah tahsin al-hikam memberikan tanda pagar (hashtag) sebagai kata kunci dan tag ke akun akun yang mempunyai banyak follower.

4. Menjawab segala pertanyaan dari follower untuk menandakan bahwa akun aktif.

\section{DAFTAR PUSTAKA}

Alma, (2013), Manajemen Pemasaran Dan Pemasaran Jasa, CV Alfabeta, Bandung.

Arikunto, Suharsimi (2010), Prosedur Penelitian: Suatu Pendekatan Praktis. Edisi Revisi, Rineka Cipta. Jakarta

Ariyanto, Aris (2019), The Influence of Price and Service Quality on Customer Satisfaction at PT Sarana Estate 
Ariyanto, A., Sudarsono, A., Ivantan, I., Akbar, M. F., \& Munarsih, M. (2020). Pengembangan Potensi Destinasi Wisata Curug Angkrek melalui Media Sosial di Kp. Cimuncang, Desa Karangnunggal, Kabupaten Tasikmalaya Jawa Barat. BAKTIMAS: Jurnal Pengabdian pada Masyarakat, 2(2), 95-99.

Assauri, (2012), Manajemen Pemasaran, Rajawali Pers, Jakarta.

Daryanto, (2011), Strategi Menaklukkan. Pasar Melalui Riset Ekuitas dan Perilaku Merek. Cetakan Ketiga. Gramedia, Jakarta.

Effendi M. Guntur, (2010), Transformasi Manajemen Pemasaran+Membangun. Citra Negara. Sagung Seto, Jakarta.

Hasan, (2009), Marketing, Yogyakarta: Media Pressindo.

Jhon D. Millet, (2012), Management in the public service: The quest for effective performance. New York: McGraw-Hill.

Kotler dan Amstrong, (2012), Prinsip-Prinsip Pemasaran Jilid I. Erlangga, Jakarta.

dan Keller, (2012), Manajemen Pemasaran, Edisi 12, Penerjemah Benyamin Molan, Indeks, Jakarta.

Legawa, Aby. (2008). Komponen Produk Pariwisata dengan Acuan Khusus. Jakarta: Gramedia Pustaka

Mardiana, S., Supriyatna, W., Hasanah, Y. M., Zakaria., \& Indirasari, I. (2010). Optimalisasi Anggaran Keuangan Di Masa Pandemi Pada Desa Cicalengka Kabupaten Pagedangan Tangerang. DEDIKASI PKM. 1 (3).

Munarsih, M., Akbar, M. F., Ariyanto, A., Ivantan, I., \& Sudarsono, A. (2020). Pelatihan Digital Marketing Dalam Meningkatkan Kompetensi Siswa Untuk Berwirausaha Pada Smk Muhammadiyah Parung-Bogor. Jurnal Pengabdian Dharma Laksana, 3(1), 22-28.

Rangkuty, (2009), Riset Pemasaran, Gramedia pustaka Utama, Jakarta.

Robbins dan Coulter, (2014), Manajemen, Edisi ke sepuluh jilid 1, Erlangga, Jakarta.

Rulli Nasrullah, (2016), Media Sosial Perspektif Komunikasi, Budaya, Sosioteknologi, Cet.kedua, Simbiosa Rekatama Media, Bandung

Solihin, D., Prasetiyani, D., Sari, A. R., Sugiarti, E., \& Sunardi, D. (2020). PEMANFAATAN BOTOL BEKAS SEBAGAI PENYARING AIR BERSIH SEDERHANA BAGI WARGA DESA CICALENGKA KECAMATAN PAGEDANGAN KABUPATEN TANGERANG. DEDIKASI PKM, 1(3), 98-102

Stelzner, MA (2012). Social Media Marketing Industry Report. How Marketers Are Using Social Media to Grow Their Business

Stockdale, Ahmed, \& Scheepers. (2012). Identifying Business Value from The Use of Social Media: An SME Perspective. Pacific Asia Conference on Information Systems. Association for Inforamtion System Electronic Library

Supranto, (2012), Metode Riset Aplikasinya Dalam Pemasaran, Lembaga Penerbitan Fakultas Ekonomi Universitas Indonesia, Jakarta.

Swastha dan Irawan, (2011), Pemasaran Modern, Liberty, Yogyakarta. 